\title{
Klebsiella spp.'ye Karşı Bazı Antibiyotiklerin Aktivitelerinin Box-Behnken Modeli Kullanılarak İstatistiksel Optimizasyonu
}

\author{
Hatice Aysun MERCIMEK TAKCI ${ }^{1 *}$, Pemra BAKIRHAN² , Hüseyin KAYRAN ${ }^{3}$, Kardelen \\ BÜLBÜL ${ }^{4}$
}

\begin{abstract}
${ }^{1,3}$ Kilis 7 Aralık Üniversitesi, Fen-Edebiyat Fakültesi, Moleküler Biyoloji ve Genetik Bölümü, Kilis, Türkiye ${ }^{2}$ Kilis 7 Aralık Üniversitesi, Fen Bilimleri Enstitüsü, Moleküler Biyoloji ve Genetik Anabilim Dalı, Kilis, Türkiye ${ }^{4}$ Mersin Üniversitesi, Tıp Fakültesi Çiftlikköy Kampüsü 33343 Yenişehir, Mersin
\end{abstract}

*Sorumlu Yazar: mersimek@hotmail.com

Geliş Tarihi: 23.01 .2020

Kabul Tarihi: 29.05.2020

\section{Öz}

Eritromisin (15 $\mu \mathrm{g} /$ disk), kloramfenikol (30 $\mu \mathrm{g} /$ disk), streptomisin (10 $\mu \mathrm{g} / \mathrm{disk})$ ve tetrasiklin (30 $\mu \mathrm{g} / \mathrm{disk})$ standart antibiyotiklerinin Klebsiella spp.'ye karşı antibakteriyel aktivitelerinin arttırılması için inkübasyon sıcaklığ $\left(25-49^{\circ} \mathrm{C}\right)$, besiyeri başlangıç pH'sı (5-10) ve inkübasyon süresi (6-24 saat) bağımsız değişkenlerinin etkisi Box Behnken deney tasarım modeli kullanılarak optimize edilmiştir. Antibakteriyel aktiviteler Kirby-Bauer disk difüzyon metoduna göre analiz edilmiştir. Eritromisin ve streptomisin standart antibiyotikleri için, inkübasyon sıcaklığı, $\mathrm{pH}$ ve inkübasyon süresi değişkenleri ile ajanların etki mekanizmaları arasında pozitif bir korelasyon bulunmuştur. İnkübasyon sıcaklığının $25^{\circ} \mathrm{C}$ 'den $49^{\circ} \mathrm{C}$ 'ye; besiyeri pH'sının 5'den 10'a ve inkübasyon süresinin 6 saatten 24 saate artışının suş üzerindeki antibakteriyel aktivitenin artışına sebep olduğu saptanmıştır. Eritromisin için en yüksek aktivite $22.50 \mathrm{~mm}$ inhibisyon zonu çapı ile $49^{\circ} \mathrm{C}$; $\mathrm{pH} 7.5$ ve 6 saat; $25^{\circ} \mathrm{C}$; pH 10.00 ve 15 saatte belirlenmiştir. Streptomisin için ise $25^{\circ} \mathrm{C}$; $\mathrm{pH} 10.00$ ve 15 saatte en yüksek inhibisyon zonu $27.00 \mathrm{~mm}$ olarak kaydedilmiştir. Varyans analizi sonuçlarına göre, eritromisin ve streptomisin aktivitelerinin arttırılmasında model istatistiksel olarak anlamlı bulunurken $(\mathrm{p}<0.05)$, kloramfenikol ve tetrasiklin antibiyotikleri için istatistiksel açıdan anlamsız ( $>00.05)$ bulunmuştur. Streptomisin aktivitesi üzerinde inkübasyon sıcaklığının etkisi, eritromisin üzerinde ise inkübasyon süresinin etkisi istatistiksel olarak önemli bulunmuştur. Her iki antibiyotiğin aktivitesi üzerinde inkübasyon sıcaklığı ve pH faktörlerinin etkileşimlerinin önemli olduğu saptanmıştır.

Anahtar Kelimeler: Yüzey yanıt metodu, Klebsiella spp., antibiyotikler.

\section{Statistical Optimization of Activities of Some Antibiotics to Klebsiella spp. by Using Box-Behnken Design}

\begin{abstract}

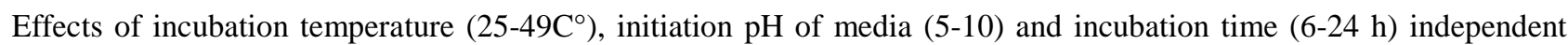
variables for enhancing antibacterial activities of erythromycin (15 $\mu \mathrm{g} / \mathrm{disc})$, chloramphenicol (30 $\mu \mathrm{g} /$ disc), streptomycin (10 $\mu \mathrm{g} /$ disc) and tetracycline (30 $\mu \mathrm{g} /$ disc) standard antibiotics on Klebsiella spp.were optimized by using Box Behnken design model. Antibacterial analyses were performed by Kirby-Bauer disc diffusion method. A positive correlation was found between antibacterial activity and tested independent variables for erythromycin and streptomycin antibiotics. The increases of incubation temperature, $\mathrm{pH}$ and incubation time in the analyzed model were caused to the increase in antibacterial activity against Klebsiella spp. The highest activity for erythromycin was $22.50 \mathrm{~mm}$. This activity was

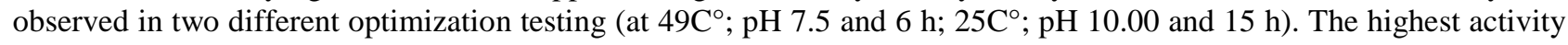

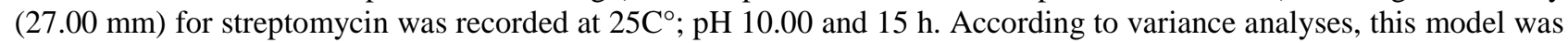
statistically significant in enhancing activities of erythromycin and streptomycin $(\mathrm{p}<0.05)$, but statistically insignificant for chloramphenicol and tetracycline. The effect of incubation temperature on streptomycin activity and incubation time on erythromycin activity was statistically significant found $(\mathrm{p}>0.05)$. The interactions of incubation temperature and $\mathrm{pH}$ factors on activity of both antibiotics were detected to be statistically significant.
\end{abstract}

Keywords: Response surface method, Klebsiella spp., Antibiotics. 


\section{Giriş}

Antibiyotikler, bakterilerin neden olduğu enfeksiyon hastalıklarına karşı savaşta kritik öneme sahip ilaçlardır (Odonkor ve Addo, 2011). Bu hastalıkları tedavi etmek için antibiyotiklerin 70 yılı aşkın kullanımı ve enfeksiyonların prevalansındaki dramatik artış patojenlerin çoklu ve genişlemiş ilaç direncine neden olmaktadır (Navon-Venezia ve ark., 2017). Bununla birlikte, antibiyotik ilaç terapisine karşı direnç gösteren hastalık sebebi bakteriler gün geçtikçe artan sağlık problemlerine neden olmaktadır. Yara enfeksiyonu, bel soğukluğu, verem, zatürre, septisemi ve çocuklarda görülen kulak hastalıkları antibiyotiklerle tedavi edilmesi oldukça zorlaşan hastalıklarından sadece bir kaçıdır (Odonkor ve Addo, 2011). Antibiyotik dirençliliği bir mültifaktöriyel kompleks prosestir (NavonVenezia ve ark., 2017). Bir taraftan yeni ilaç geliştirilme çalışmaları sürerken, diğer taraftan bu ilaçlara karşı bakterilerin hızlıca direnç göstermesi antibiyotiklerle tedaviyi zorlaştırmaktadır. Antibiyotiklere karşı direnç mekanizmasının başlıca 4 tipi söz konusudur: 1. Doğal direnç, 2. Geliştirilmiş direnç, 3. Çapraz direnç, 4. Çoklu ilaç direnci ve kolistin (polimiksin E) direnci (Cesur ve Demiröz, 2013).

Dış membran yapısının ve periplazmik beta-laktamazlar gibi savunma mekanizmaların varlığından dolayı Gram-negatif bakteriler Gram-pozitiflere göre antimikrobiyal ajanlara karşı daha dirençlidir. Antibiyotik dirençli Gram-negatif bakterilerce gelişen enfeksiyonlar, yüksek ölüm oranları, uzayan hastane tedavisi ve fiyatları ile ilişkilendirilmektedir. Enterobacteriaceae ailesine ait Gram-negatif bakteriler normal intestinal floranın üyesi ve ayrıca klinik pratiklerde en çok karşılaşılan patojenler arasındadır (Ruh ve ark., 2016). Gram-negatif bakteriler arasında hastane enfeksiyonlarının en önemli sebeplerinden biri Klebsiella spp. suşlarıdır. Basil şekilli, aerobik ve fakültatif anaerobik, hareketsiz, nitrat pozitif ve mukoid koloni gösteren bu suşlar, idrar yolu enfeksiyonları, zatürre, septisemi, yara ve kan dolaşımı gibi en genel hastane enfeksiyonlarının sebebidir (Babakhani ve ark., 2015; Khaertynov ve ark., 2018).

Bu çalışmada, protein sentezinde etkili eritromisin (15 $\mu \mathrm{g} / \mathrm{disk})$, kloramfenikol (30 $\mu \mathrm{g} / \mathrm{disk})$, streptomisin (10 $\mu \mathrm{g} /$ disk) ve tetrasiklin (30 $\mu \mathrm{g} /$ disk) standart antibiyotiklerinin Kilis ili Devlet Hastanesi Mikrobiyoloji Biriminden temin edilen klinik izolat Klebsiella spp. suşuna karşı gösterdiği antibakteriyel aktivite üzerinde sicaklık, zaman ve $\mathrm{pH}$ parametrelerinin etkileri yanıt yüzey metodolojisinin Box Behnken deney tasarım modeli kullanılarak optimize edilmiştir.

\section{Materyal ve Metot}

Kilis ili Devlet Hastanesine muayene için gelen hastanın idrarından örnek alınıp Eosin Methylen Blue (EMB) agardaki koloni morfolojisine göre tiplendirilen Klebsiella spp. suşunun 
laboratuvarımızda Gr boyanma, indol, metil kırmızısı, Voges Proskauer ve sitrat testlerindeki davranışlarına göre tanımlanması yapılmıştır.

Yüzey yanıt metodolojisinin Box Behnken deney tasarım modeli kullanılarak Klebsiella spp. suşunun antibiyotik direnç/hassasiyet genlerinin ekspresyonu üzerinde sıcaklık, $\mathrm{pH}$ ve zaman parametrelerinin etkileri incelenmiştir. Bu modele göre belirtilen $\mathrm{pH}$ aralıklarında hazırlanan LuriaBertani (LB) broth besiyerlerinde, Tablo 1'de verilen sıcaklık ve zaman koşullarında geliştirilen kültürlerin yoğunluğu fizyolojik tuzlu su (\%0.9 NaCl) ile $0.5 \mathrm{MacFarland} \mathrm{standart} \mathrm{bulanıklığına} \mathrm{göre}$ ayarlanmıştır.

Standart bulanıklığa ayarlanan Klebsiella spp. suşu steril eküvyon çubukları ile Mueller Hinton Agar (MHA) besi yerine inoküle edilmiştir. Kirby-Bauer disk difüzyon yöntemi kullanılarak antibakteriyel analizler sürdürülmüştür. Besiyerine inokülasyonu takiben eritromisin (15 $\mu \mathrm{g} / \mathrm{disk})$, kloramfenikol (30 $\mu \mathrm{g} / \mathrm{disk})$, streptomisin (10 $\mu \mathrm{g} / \mathrm{disk})$ ve tetrasiklin (30 $\mu \mathrm{g} / \mathrm{disk})$ antibiyotik diskleri eşit aralıklarla yerleştirilmiştir. İnkübasyon süresini takiben disklerin etrafında bakterilerin üremediği şeffaf zonların varlı̆̆ incelenmiştir.

Avrupa Antimikrobiyal Duyarlılık Testi Komitesi (EUCAST) tarafından ifade edilen hassasiyet/direnç zon çaplarına göre kullanılan antibiyotiklerin söz konusu klinik izolat üzerindeki etkileri değerlendirilmiştir. Tüm antibakteriyel analizler üç tekrarlı yürütülmüştür.

Box-Behnken deney modeli, 2 seviyeli 3 faktöriyellik tasarımda tüm değişkenlerin (X1, X2 ve X3) orta değerlerinin alındığı merkez noktada toplamda 14 adet deney noktası içermektedir. 3 adet bağımsız (sıcaklık, pH ve inkübasyon süresi) değișkenin belirlendiği modelde tüm analizler 3 tekrarlı yürütülmüştür (Tablo 1).

Tablo 1. Antimikrobiyal çalışmada incelenen parametrelerin seviye değerleri

\begin{tabular}{cccc}
\hline Seviye No & Sıcaklık $\left({ }^{\circ} \mathbf{C}\right)$ & $\mathbf{p H}$ & Zaman (saat) \\
\hline-1 & 25 & 5.00 & 6.00 \\
0 & 37 & 7.50 & 15.00 \\
1 & 49 & 10.00 & 24.00 \\
\hline
\end{tabular}

Tablo 2'de verilen deney planına göre üç bağımsız değişkenin incelendiği 2 dereceden yanıt yüzey modelinde polinomal denklem kullanılarak her bir faktör değerlendirilmiştir. Modele ilişkin eşitlik aşağıda verilmiştir.

$$
Y=\beta_{0}+\sum_{i=1}^{N} \beta_{i} \times X_{i}+\sum_{i=1}^{N} \beta_{i i} \times X_{i}^{2}+\sum_{i=1}^{N-1} \sum_{j=i+1}^{N} \beta_{i j} \times X_{i j}
$$


Buna göre $\mathrm{Y}$ sistemin cevabı, $\mathrm{N}$ değişken sayısı $(\mathrm{N}=3), X i$ ve $X i j$ bağımsız değişken, $\beta 0, \beta i$, $\beta i i$ ve $\beta i j$ sabit ve modelin regresyon katsayısını ifade etmektedir. Veri analizleri için "Design Expert statistical software” (Design Expert 8.0.7) kullanılmıştır. Modelin uyumluluğu kuadratik model varyans analizi (ANOVA) ile test edilmiştir.

Tablo 2. Üç bağımsız değişken için Box-Behnken deneme planı, 3 merkez noktalı (4, 11 ve 13) 14 deney

\begin{tabular}{cccc}
\hline Deney No & $\mathbf{X}_{\text {1(SICAKLIK) }}$ & $\mathbf{X}_{\mathbf{2 ( p H )}}$ & $\mathbf{X}_{\mathbf{3} \text { (inkübasyon süresi) }}$ \\
\hline 1 & -1 & 1 & 0 \\
2 & 1 & 0 & -1 \\
3 & 1 & -1 & 0 \\
4 & 0 & 0 & 0 \\
5 & 0 & 1 & 1 \\
6 & 0 & -1 & -1 \\
7 & 0 & -1 & 1 \\
8 & -1 & 0 & -1 \\
9 & 1 & 0 & 1 \\
10 & 0 & 1 & -1 \\
11 & 0 & 0 & 0 \\
12 & -1 & 0 & 1 \\
13 & 0 & 0 & 0 \\
14 & -1 & 1 & 0 \\
\hline
\end{tabular}

\section{Bulgular ve Tartışma}

Farklı etki mekanizmalarına sahip eritromisin (15 $\mu \mathrm{g} / \mathrm{disk})$, kloramfenikol (30 $\mu \mathrm{g} / \mathrm{disk})$, streptomisin (10 $\mu \mathrm{g} / \mathrm{disk})$ ve tetrasiklin (30 $\mathrm{\mu g} / \mathrm{disk})$ standart antibiyotikleri bakterilerde protein sentezini inhibe ederek doza bağımlı statik/sidal etki göstermektedir. Box Behnken deneme planı ile elde edilen Klebsiella spp. suşunun eritromisin ve streptomisine karşı gösterdiği dirençlilik/hassasiyete yönelik deneysel değerler ve tahmin edilen değerler Tablo 3 ’te verilmiştir. 
Tablo 3. Klebsiella spp. suşunun eritromisin ve streptomisine karşı gösterdiği dirençlilik/hassasiyetin deneysel ve tahmin edilen değerleri

\begin{tabular}{|c|c|c|c|c|c|c|c|}
\hline \multirow[b]{3}{*}{ Deneme no } & \multirow{3}{*}{$\begin{array}{c}\begin{array}{c}\text { Sicaklık } \\
\left({ }^{\circ} \mathrm{C}\right)\end{array} \\
\mathrm{X} 1\end{array}$} & \multirow{3}{*}{$\begin{array}{r}\text { pH } \\
\text { X2 }\end{array}$} & \multirow{3}{*}{$\begin{array}{c}\text { İnkübasyon } \\
\text { süresi (saat) }\end{array}$} & \multicolumn{4}{|c|}{ Dirençlilik/Hassasiyet Zon çapı (mm) } \\
\hline & & & & \multicolumn{2}{|c|}{ Eritromisin } & \multicolumn{2}{|c|}{ Streptomisin } \\
\hline & & & & Deneysel & $\begin{array}{c}\text { Tahmin } \\
\text { Edilen }\end{array}$ & Deneysel & $\begin{array}{l}\text { Tahmin } \\
\text { Edilen }\end{array}$ \\
\hline 1 & 49.00 & 7.50 & 6.00 & 22.50 & 20.64 & 27.00 & 26.86 \\
\hline 2 & 37.00 & 7.50 & 15.00 & 11.00 & 11.02 & 21.50 & 21.63 \\
\hline 3 & 25.00 & 10.00 & 15.00 & 22.50 & 22.71 & 22.50 & 22.71 \\
\hline 4 & 37.00 & 7.50 & 15.00 & 17.50 & 16.33 & 20.00 & 19.33 \\
\hline 5 & 37.00 & 10.00 & 6.00 & 18.00 & 18.23 & 21.00 & 20.99 \\
\hline 6 & 37.00 & 5.00 & 24.00 & 12.50 & 12.27 & 18.50 & 18.51 \\
\hline 7 & 49.00 & 7.50 & 24.00 & 17.50 & 17.52 & 20.00 & 20.13 \\
\hline 8 & 49.00 & 5.00 & 15.00 & 10.00 & 10.23 & 18.00 & 17.99 \\
\hline 9 & 37.00 & 5.00 & 6.00 & 18.50 & 18.27 & 24.50 & 24.51 \\
\hline 10 & 25.00 & 7.50 & 6.00 & 12.50 & 12.48 & 19.00 & 18.87 \\
\hline 11 & 25.00 & 10.00 & 15.00 & 15.50 & 16.33 & 20.00 & 19.33 \\
\hline 12 & 37.00 & 10.00 & 24.00 & 14.00 & 13.98 & 19.00 & 18.87 \\
\hline 13 & 25.00 & 7.50 & 24.00 & 16.00 & 16.33 & 18.00 & 19.33 \\
\hline 14 & 37.00 & 7.50 & 15.00 & 19.00 & 20.64 & 21.00 & 22.64 \\
\hline
\end{tabular}

Antibiyotik dirençlilik/hassasiyetine yönelik üç bağımsız değişkenler arasındaki ilişkiyi ortaya koyan regresyon denklemi aşağıda gibi hesaplanmıştır.

$$
\begin{aligned}
Y_{\text {eritromisin }}= & 16.33+1.27 \mathrm{X}_{1}+0.23 \mathrm{X}_{2}+0.275 \mathrm{X}_{3}-9.51 \mathrm{X}_{1} * \mathrm{X}_{2}+0.88 \mathrm{X}_{1} * \mathrm{X}_{3}+0.12 \mathrm{X}_{2} * \mathrm{X}_{3}-2.96 \mathrm{X}_{1}{ }^{2}- \\
& 1.21 \mathrm{X}_{2}{ }^{2} \\
Y_{\text {streptomisin }}= & +19.33+2.32 \mathrm{X}_{1}+0.30 \mathrm{X}_{2}+0.94 \mathrm{X}_{3}-3.80 \mathrm{X}_{1} * \mathrm{X}_{2}+0.50 \mathrm{X}_{1} * \mathrm{X}_{3}+0.12 \mathrm{X}_{2} * \mathrm{X}_{3}+1.42 \mathrm{X}_{1}{ }^{2}+ \\
& 0.29 \mathrm{X}_{2}{ }^{2}
\end{aligned}
$$

Eritromisin ve streptomisin antibiyotiklerin etki mekanizmaları üzerinde etkisi incelenen bağımsız değişkenlerine yönelik regresyon eşitlikleri incelendiğinde, her iki standart antibiyotik için $\beta_{i}, \beta_{i i}$ ve $\beta_{i j}$ katsayılarının pozitif değerlere sahip olması, inkübasyon sıcaklığı, $\mathrm{pH}$ ve inkübasyon süresinin değişkenleri ile antibiyotiklerin etki mekanizmaları arasında pozitif bir korelasyon olduğu gözlenmektedir. İnkübasyon sıcaklığın $25^{\circ} \mathrm{C}$ 'den $49^{\circ} \mathrm{C}$ 'ye; besiyeri pH'sının 5'den 10 'a ve inkübasyon süresinin 6 saatten 24 saate artışının standartların aktivitelerinin artmasına sebep olmaktadır. $\beta_{i}$ katsayısı değerlerinin +1.27 ve 2.32 olması, her iki standarttın test suşuna karşı aktivitesini etkileyen en önemli bağımsız değişkenin inkübasyon sıcaklığı olduğunu göstermektedir.

Regresyon sonucu elde edilen ikinci dereceden polinomiyal modelin uyumluluğu korelasyon katsayısı $\left(\mathrm{R}^{2}\right)$ ile test edilmiş olup; hesaplanan korelasyon katsayısı $\left(\mathrm{R}^{2}\right)$, eritromisin için 0.9565; streptomisin için ise 0.9071 olması söz konusu modelin, deneysel verileri ile tahmin edilen verilerin tutarlı olduğunu göstermektedir. 
Tablo 4. Eritromisinin test suşuna karşı aktivite varyans analiz sonucu

\begin{tabular}{cccccc}
\hline & $\begin{array}{c}\text { Serbestlik } \\
\text { derecesi }\end{array}$ & $\begin{array}{c}\text { Kareler } \\
\text { toplamı }\end{array}$ & $\begin{array}{c}\text { Kare } \\
\text { ortalaması }\end{array}$ & $\begin{array}{c}\text { F- } \\
\text { değeri }\end{array}$ & P-değeri \\
\hline Model & 8 & 188.78 & 23.60 & 13.76 & $<0.0052$ \\
$\mathbf{X}_{\mathbf{1}}$ & 1 & 9.00 & 9.00 & 5.25 & 0.0706 \\
$\mathbf{X}_{\mathbf{2}}$ & 1 & 0.30 & 0.30 & 0.18 & 0.6923 \\
$\mathbf{X}_{3}$ & 1 & 60.50 & 60.50 & 35.27 & $<0.0019$ \\
$\mathbf{X}_{\mathbf{1}} \mathbf{X}_{\mathbf{2}}$ & 1 & 76.00 & 76.00 & 44.30 & $<0.0012$ \\
$\mathbf{X}_{\mathbf{1}} \mathbf{X}_{\mathbf{3}}$ & 1 & 3.06 & 3.06 & 1.79 & 0.2391 \\
$\mathbf{X}_{\mathbf{2}} \mathbf{X}_{\mathbf{3}}$ & 1 & 0.063 & 0.063 & 0.036 & 0.8561 \\
$\mathbf{X}_{\mathbf{1}}{ }^{2}$ & 1 & 15.00 & 15.00 & 8.75 & 0.0316 \\
$\mathbf{X}_{\mathbf{2}}{ }^{2}$ & 1 & 2.50 & 2.50 & 1.46 & 0.2811 \\
$\mathbf{X}_{\mathbf{3}}{ }^{2}$ & 0 & 0.000 & & & \\
Kalıntı & 5 & 8.58 & 1.72 & & \\
Uyum & 2 & 0.29 & 0.14 & 0.052 & 0.9505 \\
eksikliği & & & & & \\
Net hata & 3 & 8.29 & 2.76 & & \\
\hline
\end{tabular}

Tablo 4 ve 5'te test edilen her bir bağımsız değişkenin eritromisin ve streptomisin aktivitesi üzerindeki etkisi ANOVA varyans analizi ile belirlenmiş olup, her bir katsayının önemini gösteren P ve $\mathrm{F}$ değerleri verilmiştir.

Tablo 5. Streptomisinin test suşuna karşı aktivite varyans analiz sonucu

\begin{tabular}{cccccc}
\hline & $\begin{array}{c}\text { Serbestlik } \\
\text { derecesi }\end{array}$ & $\begin{array}{c}\text { Kareler } \\
\text { toplamı }\end{array}$ & $\begin{array}{c}\text { Kare } \\
\text { ortalaması }\end{array}$ & $\begin{array}{c}\text { F- } \\
\text { değeri }\end{array}$ & P-değeri \\
\hline Model & 8 & 86.82 & 10.85 & 6.10 & $<0.0310$ \\
$\mathbf{X}_{\mathbf{1}}$ & 1 & 30.18 & 30.18 & 16.97 & $<0.0092$ \\
$\mathbf{X}_{\mathbf{2}}$ & 1 & 0.52 & 0.52 & 0.29 & 0.6133 \\
$\mathbf{X}_{3}$ & 1 & 7.03 & 7.03 & 3.95 & 0.1035 \\
$\mathbf{X}_{\mathbf{1}} \mathbf{X}_{\mathbf{2}}$ & 1 & 12.11 & 12.11 & 6.81 & $<0.0477$ \\
$\mathbf{X}_{\mathbf{1}} \mathbf{X}_{\mathbf{3}}$ & 1 & 1.00 & 1.00 & 0.56 & 0.4872 \\
$\mathbf{X}_{\mathbf{2}} \mathbf{X}_{\mathbf{3}}$ & 1 & 0.062 & 0.062 & 0.035 & 0.8587 \\
$\mathbf{X}_{\mathbf{1}}{ }^{2}$ & 1 & 3.44 & 3.44 & 1.93 & 0.2230 \\
$\mathbf{X}_{\mathbf{2}}{ }^{2}$ & 1 & 0.15 & 0.15 & 0.082 & 0.7861 \\
$\mathbf{X}_{\mathbf{3}}{ }^{2}$ & 0 & 0.000 & & & \\
Kalıntı & 5 & 8.89 & 1.78 & & \\
Uyum & 2 & 0.10 & 0.051 & 0.018 & 0.9827 \\
eksikliği & & & & & \\
Net hata & 3 & 8.79 & 2.93 & & \\
\hline
\end{tabular}

Antibakteriyel analizler için test edilen modelin P değerinin (prob>f) 0.05 'ten küçük olması (0.0052) önerilen modelin, bağımsız değişkenler ile eritromisin aktivitesi arasındaki ilişkinin incelenmesi için istatistiksel olarak önemli olduğunu göstermektedir. Tablo 4'te $\mathrm{P}$ değerlerine bakıldığında, $X_{3}$ faktörünün yani inkübasyon süresinin eritromisin aktivitesi üzerinde etkisi istatistiksel olarak anlamlıdır. 
Antibakteriyel analizler için test edilen modelin $P$ değerinin (prob $>f$ ) 0.05 'ten küçük olmas1 (0.0310) önerilen modelin, bağımsız değişkenler ile streptomisin aktivitesi arasındaki ilişkinin incelenmesi için istatistiksel olarak anlamlı olduğunu göstermektedir. Tablo 5 'te $\mathrm{P}$ değerlerine bakıldığında, $X_{1}$ faktörünün yani inkübasyon sıcaklığının streptomisin aktivitesi üzerinde etkisi istatistiksel olarak anlamlıdır.

Bağımsız değişkenlerin etkileşimleri incelendiğinde, inkübasyon sıcaklığı ve pH faktörlerinin eritromisin ve streptomisin aktivitesi üzerindeki etkisinin önemli olduğu Tablo 4 ve 5'te gözlenmektedir $(p<0.05)$. Regresyon eşitliklerine bakıldığında bu iki bağımsız değişkenin negatif bir korelasyon ile etkileşim gösterdiği saptanmaktadır.

Kloramfenikol ve tetrasiklin antibiyotikleri için model sonuçları değerlendirildiğinde, korelasyon katsayısı $\left(\mathrm{R}^{2}\right)$ kloramfenikol için 0.7274; tetrasiklin için ise 0.8417’dir. Varyans analiz sonuçlarına göre her iki antibiyotik için modelin $P$ değeri (prob $>$ f) 0.05 'ten büyüktür. Buna göre veriler istatistiksel olarak anlamsızdır. Antibiyotiklerin suş üzerindeki aktiviteleri ve test edilen bağımsız değişkenler arasında herhangi bir etkileşim söz konusu değildir.

Eritromisin antibiyotiğinin Klebsiella spp.'ye karşı gösterdiği antibakteriyel aktivite için çizdirilen üç boyutlu yanıt yüzey grafikleri Şekil 1'de verilmiştir.

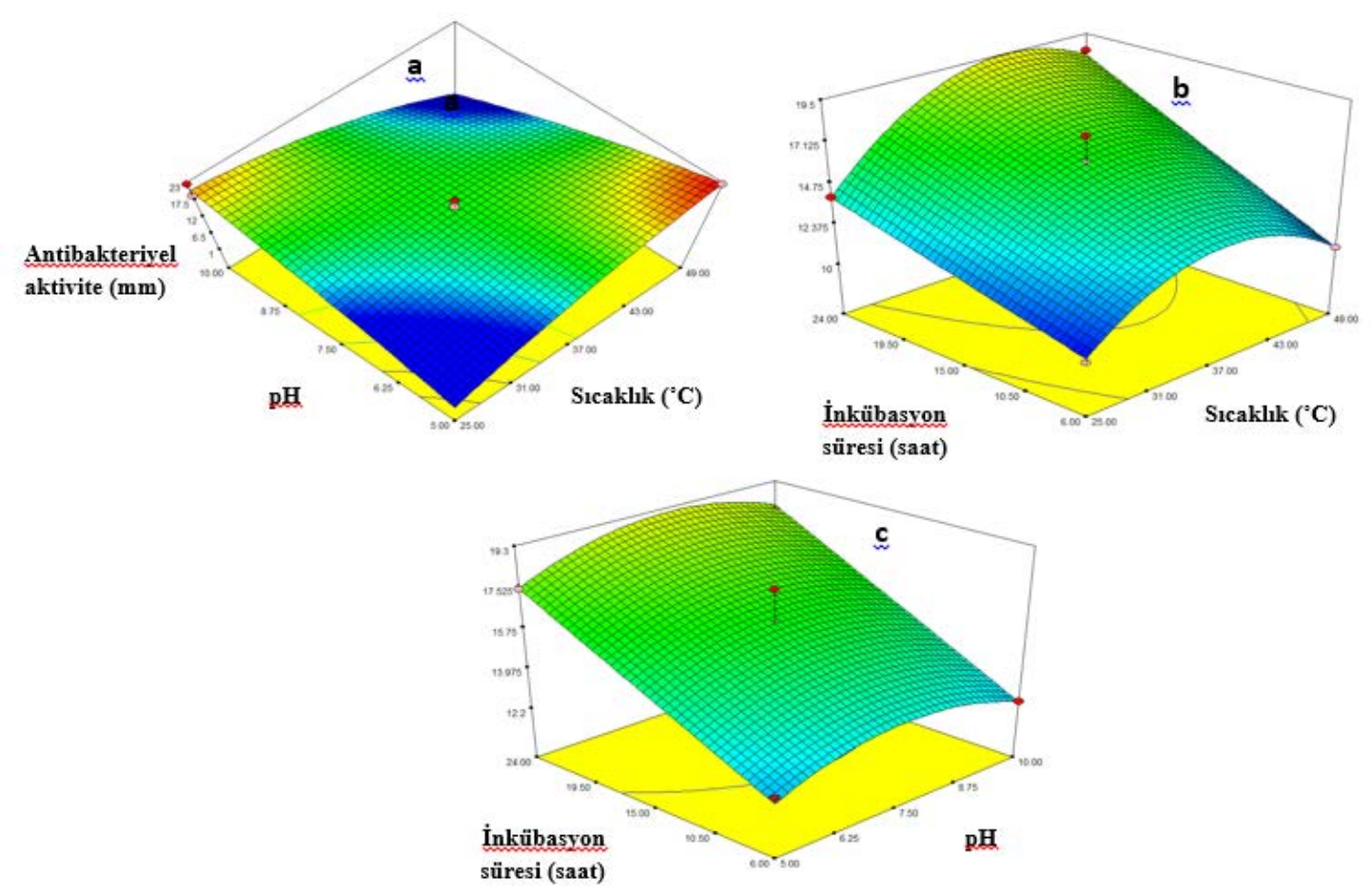

Şekil 1. Eritromisin aktivitesi analizinin yüzey yanıt grafiği

a) Sabit inkübasyon süresinde (15.00); $\mathrm{pH}$ ve inkübasyon sıcaklı̆̆ $\left({ }^{\circ} \mathrm{C}\right)$

b) Sabit pH aralığında (7.50); inkübasyon süresi (saat) ve inkübasyon sıcaklığı $\left({ }^{\circ} \mathrm{C}\right.$ )

c) Sabit inkübasyon sicaklığında $\left(37^{\circ} \mathrm{C}\right)$; inkübasyon süresi (saat) ve $\mathrm{pH}$ 
Sabit inkübasyon süresinde (15.00 saat), pH ve inkübasyon sıcaklığı $\left({ }^{\circ} \mathrm{C}\right)$ bağımsız değişkenlerinin etkisi incelendiğinde, $\mathrm{pH} 5.0^{\prime}$ da sıcaklığın $25^{\circ} \mathrm{C}$ 'den $49^{\circ} \mathrm{C}$ 'ye yükselmesi eritromisin aktivitesini $1.15 \mathrm{~mm}$ zon çapından $22.71 \mathrm{~mm}$ 'ye yükselttiği hesaplanmıştır. Ancak pH 10.00 iken, sıcaklık artışının aktiviteyi 20.64 mm'den $4.15 \mathrm{~mm}$ zon çapına kadar azalttığı belirlenmiştir. Optimizasyon besiyerinin başlangıç pH'sı ve inkübasyon sıcaklığındaki birlikte artış antibakteriyel aktivitenin azalmasına sebep olmaktadır. Bu etkileşim sonuçları regresyon denklemindeki negatif korelasyon sonucunu desteklemektedir.

Şekil 1.b'de sabit pH (7.50) aralığında inkübasyon süresi ve inkübasyon sıcaklığının eritromisin aktivitesine etkileri incelendiği model grafiğinde inkübasyon sıcaklığı ve süresinin artmasına bağlı olarak Klebsiella spp.'ye karşı antibakteriyel aktivitenin arttığı gözlenmektedir. Sabit inkübasyon sıcaklığında ise $\left(37^{\circ} \mathrm{C}\right)$ besiyerinin $\mathrm{pH}$ 'sı arttıkça antibakteriyel aktivitenin de arttığı belirlenmiştir (Şekil 1.c). Yüzey yanıt grafiğine göre $\mathrm{mm}$ cinsinden eritromisin için belirlenen en yüksek antibakteriyel aktivite $22.50 \mathrm{~mm}$ inhibisyon zon çapı ile 15 saatlik sabit inkübasyon süresinde $25^{\circ} \mathrm{C}$, pH 10 ve $49^{\circ} \mathrm{C}$, pH 5.0 optimizasyon koşullarında rastlanmıştır. En düşük antibakteriyel aktivite ise $25^{\circ} \mathrm{C}$, pH 7.50 ve 6 saatlik inkübasyon süresinde $10 \mathrm{~mm}$ inhibisyon zon çapı olarak belirlenmiştir.

Tablo 6. Enterobacteriaceae için EUCAST referans değerleri

\begin{tabular}{lccc}
\hline & $\begin{array}{c}\text { Duyarlılık } \\
(\mathrm{S})\end{array}$ & $\begin{array}{c}\text { Orta dirençli } \\
(\mathrm{I})\end{array}$ & $\begin{array}{c}\text { Dirençlilik } \\
(\mathrm{R})\end{array}$ \\
\hline Eritromisin $(15 \mu \mathrm{g} /$ disk$)$ & $\geq 23$ & $14-22$ & $\leq 13$ \\
Kloramfenikol $(30 \mu \mathrm{g} /$ disk $)$ & $\geq 18$ & $13-17$ & $\leq 12$ \\
Streptomisin $(10 \mu \mathrm{g}$ disk $)$ & $\geq 15$ & $12-14$ & $\leq 11$ \\
Tetrasiklin $(30 \mu \mathrm{g} /$ disk$)$ & $\geq 15$ & $12-14$ & $\leq 11$ \\
\hline
\end{tabular}

Yanıt yüzey grafiklerinden elde edilen veriler Tablo 6'daki EUCAST (European Committee on Antimicrobial Susceptibility Testing) sınır değerlerine göre yorumlanmıştır. 6 saatlik sabit inkübasyon süresinde sıcaklık ve $\mathrm{pH}$ etkileşimine bağlı olarak $25^{\circ} \mathrm{C}$ 'lik inkübasyon sıcaklığı ve besiyeri pH's1 7.50 iken belirlenen dirençlilik $(12.50 \mathrm{~mm})$, sıcaklık $49^{\circ} \mathrm{C}$ 'ye, $\mathrm{pH}$ ise 10.00 'a arttıkça azalmış ve hassasiyetin başladığı gözlenmiştir. Bu optimizasyon koşullarında inhibisyon zon çapı $22.50 \mathrm{~mm}$ 'ye kadar artmıştır. $37^{\circ} \mathrm{C}$ sabit inkübasyon sıcaklığında ise, $\mathrm{pH}$ ve inkübasyon süresinin etkileşimine bağlı olarak pH 7.50 ve inkübasyon süresi 15 saat iken en düşük inhibisyon zonu $11 \mathrm{~mm}$ olup dirençlilik olarak ifade edilmektedir. Tablo 3'te $37^{\circ} \mathrm{C}$ sabit inkübasyon sıcaklığındaki deneysel veriler incelendiğinde, inhibisyon zon çaplarının 11 ile $19 \mathrm{~mm}$ arasında değiştiği, dirençliliğin koşullara bağlı olarak azaldığı ve orta direncin oluştuğu belirlenmiştir.

Streptomisin antibiyotiğinin Klebsiella spp.'ye karşı gösterdiği antibakteriyel aktivite için çizdirilen üç boyutlu yanıt yüzey grafikleri Şekil 2'de verilmiştir. 

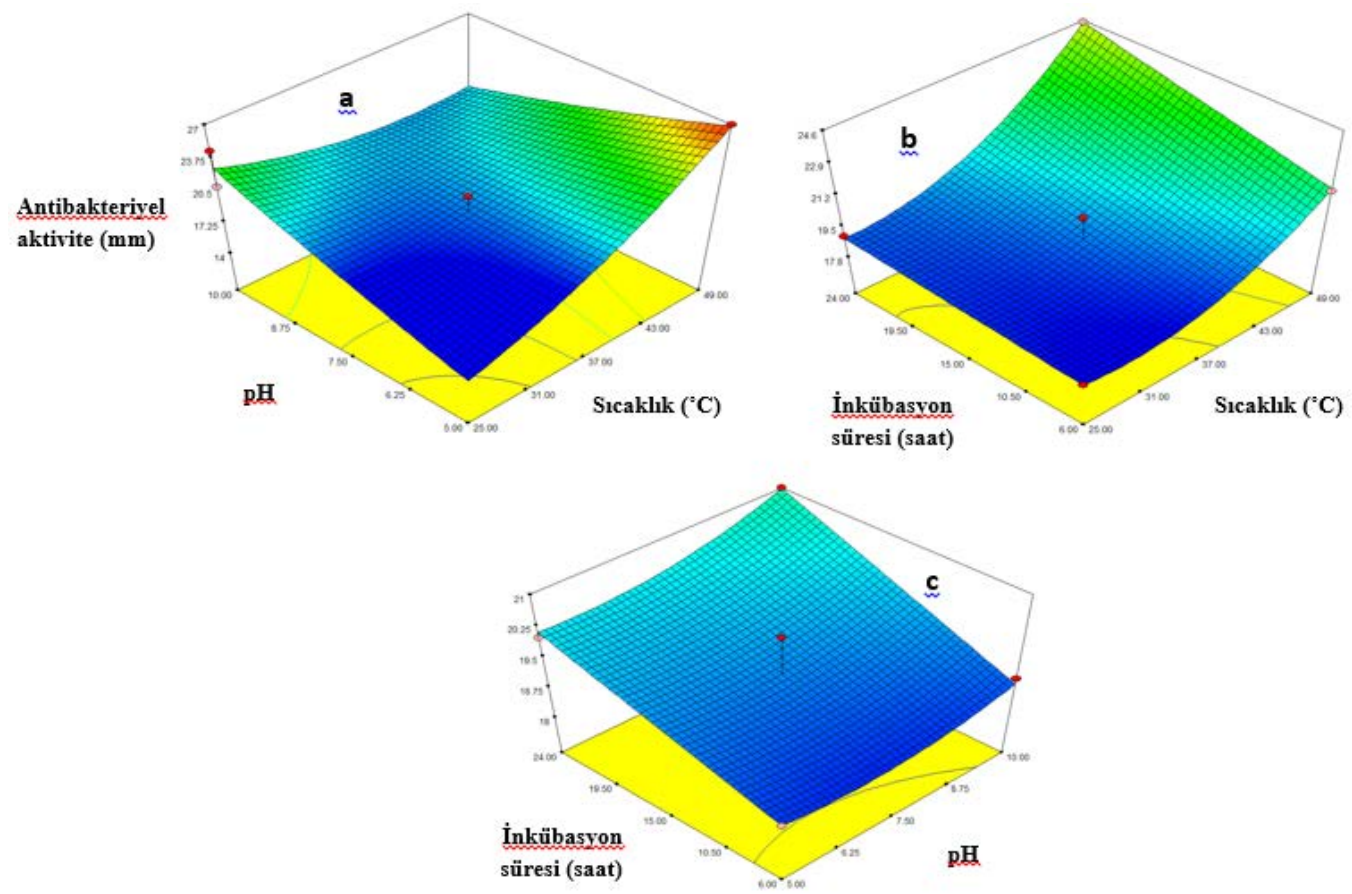

Şekil 2. Streptomisin aktivitesi analizinin yüzey yanıt grafiği

a) Sabit inkübasyon süresinde (15.00); $\mathrm{pH}$ ve inkübasyon sıcaklığ $1\left({ }^{\circ} \mathrm{C}\right)$

b) Sabit pH aralığında (7.50); inkübasyon süresi (saat) ve inkübasyon sıcaklı̆̆ $1\left({ }^{\circ} \mathrm{C}\right)$

c) Sabit inkübasyon sicaklığında $\left(37^{\circ} \mathrm{C}\right)$; inkübasyon süresi (saat) ve $\mathrm{pH}$

Şekil 2.a'ya bakıldığında sabit inkübasyon süresinde (15.00 saat), pH ve inkübasyon sıcaklığı $\left({ }^{\circ} \mathrm{C}\right)$ bağımsız değişkenlerinin etkisi incelendiğinde, $\mathrm{pH} 5$ 'te sıcaklığın $25^{\circ} \mathrm{C}$ 'den $49^{\circ} \mathrm{C}$ 'ye $\operatorname{artış1~}$ streptomisin aktivitesini 14.61 'den $26.86 \mathrm{~mm}$ zon çapına kadar arttırdığı hesaplanmıştır. EUCAST sınır değerlerine göre Klebsiella spp.'nin streptomisine karşı gösterdiği orta direncin hassasiyete değiştiği ve streptomisinin aktivitesinin arttığı saptanmıştır. Fakat besiyeri pH’s1 10.00 iken sıcaklıktaki artışın inhibisyonu 22.82 mm'den 19.86 mm zon çapına kadar azalttığı ortaya konmuştur. Streptomisin antibiyotiğine karşı hassasiyetin devam etmesine karşın inhibisyon zon çapının azaldı̆̆ gözlenmektedir. Klebsiella spp.'nin streptomisine karşı dirençlilik gösterdiği herhangi bir deneme planı koşuluna rastlanmamıştır. Tüm deneme planlarında hassasiyetlik belirlenmiş olup, en yüksek antibakteriyel aktiviteye $27 \mathrm{~mm}$ inhibisyon zon çapı besiyerinin $\mathrm{pH}$ 's 7.50 iken $49^{\circ} \mathrm{C}$ 'de 6 saatlik inkübasyon süresinde rastlanmıştır. Aynı koşullarda inkübasyon süresinin 24 saatte artışı inhibisyon çapının 27 mm'den 20.00 mm'ye kadar azaldığını göstermektedir.

Sabit inkübasyon süresi (15.00 saat) ve $\mathrm{pH}$ (7.50)'da eritromisinin antibakteriyel aktivitesinin $25^{\circ} \mathrm{C}$ 'de $12.17 \mathrm{~mm} ; 37^{\circ} \mathrm{C}$ 'de $16.33 \mathrm{~mm} ; 49^{\circ} \mathrm{C}^{\prime}$ de ise $14.64 \mathrm{~mm}$ olduğu belirlenmiştir. Eritromisine karşı düşük sıcaklıkta gözlenen direncin, sıcaklık yükseldikçe azaldığı belirlenmiştir. Sabit inkübasyon sıcaklığ $\left(37^{\circ} \mathrm{C}\right)$ ve $\mathrm{pH}(7.50)$ 'da 6 saatlik inkübasyon süresinde aktivite $13.58 \mathrm{~mm}$ 'dir. İnkübasyon süresi arttıkça inhibisyon zonunun da arttığı tespit edilmiştir (15. saatte $16.33 \mathrm{~mm} ; 24$ saatte ise $19.08 \mathrm{~mm}$ ). İnkübasyon süresindeki artış suşun antibiyotiğe karşı gösterdiği direnci azaltarak orta direnç göstermesine neden olmuştur. Sabit inkübasyon sıcaklığ $1\left(37^{\circ} \mathrm{C}\right)$ ve süresinde 
(15 saat) pH'nın artışının aktivite üzerinde etkisi incelenmiştir. pH 5.0'da inhibisyon zonu 14.90 mm; pH 7.5'da 16.33 mm; pH 10.00'da 15.36 mm olarak kaydedilmiştir. İnkübasyon süresinin artışının antibiyotiğe maruz kalma süresine bağlı olarak suş üzerindeki antibakteriyel aktivitenin artmasına; pH'nın ise bakteri gelişimine etki ederek antibiyotiğe karşı direncin azalmasına sebep olduğu söylenebilmektedir.

Streptomisin için ise sabit inkübasyon süresi (15.00 saat) ve $\mathrm{pH}$ (7.50)'da sıcaklık arttıkça sırasıyla 18.42; 19.00 ve 23.07 mm inhibitör aktivite gözlenmiştir. Bu optimizasyon koşullarındaki inkübasyon sıcaklığı artışı, eritromisin antibiyotiğine oranla streptomisinin suş üzerindeki aktivitesine daha yüksek oranda etki göstermiştir. Sabit inkübasyon sıcaklığı $\left(37^{\circ} \mathrm{C}\right)$ ve pH (7.50)' da inkübasyon süresinin 6 saatten 24 saate artışı inhibisyon zon çapını 18.39 mm'den 20.27 mm'ye arttırmıştır. Sabit inkübasyon sıcaklığı $\left(37^{\circ} \mathrm{C}\right)$ ve süresinde (15 saat) pH'nın 5.0'dan 10.00'a artış1 streptomisin aktivitesini 19.32-19.93 mm aralığında sınırlı kılmıştır.

Antibiyotiklerin aktiviteleri üzerinde farklı değişkenlerin etkisi pek çok çalışma tarafından rapor edilmiştir. De silva ve ark. (2018) inkübasyon sıcaklığın $\left(28-37^{\circ} \mathrm{C}\right)$ bakterilerin antibiyotik dirençliliği üzerindeki etkisini incelemişlerdir. İnkübasyon sıcaklığındaki $\left(28^{\circ} \mathrm{C}\right)$ farklılığın trimetoprim-sülfametoksazol karşı duyarlılığı arttırırken, aztreonama karşı ise azalttığını bildirmişlerdir. $\mathrm{Bu}$ çalışma sıcaklık parametresinin farklı antibiyotiklerin etki mekanizmaları üzerinde farklılıklar gösterebileceğine yönelik sonuçlarımızı desteklemektedir. Lin ve ark. (2017) antibiyotik dirençliliğinin temel rezervi olan çeşitli hayvan gübrelerini farklı sıcaklıkta inkübe ederek, sülfonamid dirençliliği üzerinde sıcaklığın etkisini incelemiştir. Domuz gübresinde sıcaklığın artışı (minimum $60^{\circ} \mathrm{C}$ ) sülfonamid antibiyotiklerinin miktarında azalma, tavuk gübresinde ise $30^{\circ} \mathrm{C}^{\prime}$ de yüksek oranda degradasyon gözlenmiştir. Farklı sıcaklık $\left(10,35\right.$ ve $\left.55^{\circ} \mathrm{C}\right)$ ve başlangıç $\mathrm{pH}(5,7,9$ ve 12)'larında gübrede antibiyotik dirençlilik genlerinin ekspresyon seviyesi araştırılmıştır. pH değişimi olmaksızın $55^{\circ} \mathrm{C}$ sıcaklıkta ve çevre sıcaklığında pH'nın 12'ye artışının ekspresyon seviyesinde azalmaya sebep olduğu belirlenmiştir (Li ve ark., 2020).

Macfadden ve ark. (2018) Klebsiella spp.'ye karşı 20 farklı antibiyotiğin etkisini inceledikleri çalışmada, sonuçlarımızdan farklı olarak lokal sıcaklıktaki artışın antibiyotiklere karşı gözlenen dirençlilikte \%2.2 ( $\mathrm{p}<0.0001)$ artışa sebep olduğunu rapor etmişlerdir. Diğer bir çalışmada, çevre sıcaklığındaki $10^{\circ} \mathrm{C}^{\prime}$ lik bir artışla $K$. pneumoniae suşunun 3. kuşak sefalosporinlerinlere karşı dirençliliğinde yılda \%0.9 artış kaydedilmiştir ( $<$ <0.01) (McGough ve ark., 2018). P.aeruginosa'nın imipenem, meropenem ve biapeneme karşı dirençlilik gen bölgesi (PAO1) ekspresyon seviyesi üzerinde sıcaklık etkisi incelenmiştir (Wang ve ark., 2016). PAO1 gen bölgesinde dirençlilikten sorumlu genlerin $21^{\circ} \mathrm{C}^{\prime}$ de $37^{\circ} \mathrm{C}$ 'den daha yüksek eskpre edildiği ifade edilmiştir.

Farklı fiziksel ve kimyasal uyaranlara karşı meydana gelen mikrobiyal cevap metabolizma, gen ekspresyonu, dış membran yapısı, kemotaksis ve diğer genel adaptif cevaplarda varyansyonlara neden 
olmaktadır. Bu sebeple, mikrobiyal cevap ve test edilen antibiyotiğin yapısına bağlı olarak antibiyotik dirençlilik üzerinde etkili parametrelere ilişkin farklı sonuçlar gözlenmektedir..

Bakterilerin çeşitli antibiyotiklere karşı intrinsik direncinin mekanizmalarından biri hücresel geçirimsizliktir. Bu geçirimsiz bariyeri azaltan kimyasal ajanlar çoğu antibiyotiğe karşı bakteriyel duyarlılığın arttırılmasında önemli bir role sahiptir. Eritromisin ve streptomisin gibi antibiyotiklerin gram negatif bakterilerin dış membranına penetrasyonu oldukça zayıftır ve sonuç olarak bakteriler antibiyotiklere karşı yüksek seviyede dirençlilik göstermektedir (Saha ve ark., 2008). Bu sebeple çalışmamızda istatistiksel optimizasyon metodu kullanılarak antibiyotiklerin Klebsiella spp.' ye karşı gösterdiği antibakteriyel aktivitenin bağımsız değişkenler ile arttırılması hedeflenmiştir.

\section{Sonuçlar ve Öneriler}

Literatürde Klebsiella spp.'ye karşı etkili standart antibiyotiklerin aktivitelerinin arttırılmasına ilişkin istatistiksel bir optimizasyon çalışması yer almamaktadır. Varyans analizi sonuçları değerlendirildiğinde, eritromisin ve streptomisin antibiyotiği için inkübasyon sıcaklığı, pH ve inkübasyon süresi bağımsız değişkenlerinin incelendiği model istatistiksel olarak anlamlı bulunurken; kloramfenikol ve tetrasiklin antibiyotikler için uygulanabilir bulunmamıştır. Antibiyotiklerin aktivitelerinin arttırılması için farklı bağımsız değişkenler test edilmelidir. Elde edilen test sonuçlarının in vivo uygulanabilirliği de araştırılmalıdır.

\section{Kaynaklar}

Babakhani, S., Shokri, S. and Baharvand M., (2015). Antibiotic resistance pattern of Klebsiella pneumoniae isolated from nosocomial infections in Aleshtar hospital, Lorestan province. Report of Health Care, 1(2), 55-59.

Cesur, S., and Demiröz, A.P., (2013). Antibiotics and the Mechanisms of Resistance to Antibiotics. Medical Journal of Islamic World Academy of Sciences, 21(4), 138-142.

De Silva, P.M., Chong, P., Fernando, D.M., Wesrmacott, G. and Kumar, A., (2018). Effect of incubation temperature on antibiotic resistance and virulence factors of Acinetobacter baumannii ATCC 17978. Antimicrobial Agents and Chemotherapy, 62(1), 1-11.

Khaertynov, K.S., Anokhin, V.A., Rizvanov, A.A., Davidyuk, Y.N., Semyenova, D.R.' Lubin, S.A., and Skvortsova, N.N., (2018). Virulence Factors and Antibiotic Resistance of Klebsiella pneumoniae Strains Isolated From Neonates With Sepsis, Frontiers in Medicine, 5 Article number: 225, 1-9.

Li, M.M., Ray, P., Knowlton, K.F., Pruden, A., Xia, K., Teets, C. and Dud, P. (2020). Fate of pirlimycin and antibiotic resistance genes in dairymanure slurries in response to temperature and $\mathrm{pH}$ adjustment. Science of the Total Environment, 710, 136310.

Lin, H., Zhang, J., Chen, H., Wang, JÇ, Sun, W., Zhnag, X., Yang, YÇ, Wang, Q. and Ma, J. (2017). Effect of temperature on sulfonamide antibiotics degradation, and on antibiotic resistance determinants and hosts in animal manures. Science of the Total Environment, 607-608, 725-732

MacFadden, D., McCough, S., Fisman, D., Santillana, M. and Brownstein, J. (2018). Antibiotic resistance increases with local temperature. Nature Climate Change, 8(6), 510-514.

McGough, S.F., MacFadden, D.R., Hattab, M.W., Mølbak, K. and Santillana, M. (2018). Rates of increase of antibiotic resistance and ambient temperature in Europe: a cross-national analysis of 28 countries between 2000-2016. BioRxiv 2018. 1-17. 
Navon-Venezia, S., Kondratyeva, K., and Carattoli, A., (2017). Klebsiella pneumoniae: a major worldwide source and shuttle for antibiotic resistance. FEMS Microbiology Reviews, 41, 252-275.

Odonkor, S.T., and Addo, K.K., (2011). Bacteria Resistance to Antibiotics: Recent Trends and Challenges. International Journal of Biological and Medical Research, 2(4), 1204-1210.

Ruh, E., Gazi, U., Güvenir, M., Süer, K. and Çakır, N., (2016). Antibiotic resistance rates of Pseudomonas aeruginosa, Acinetobacter baumannii and Klebsiella pneumoniae isolated from a university-affiliated hospital in North Cyprus. Turk Hijyen ve Deneysel Biyololji Dergisi, 73(4), 333-344.

Saha, S., Savage, P.B., and Bal, M., (2008) Enhancement of the efficacy of erythromycin in multiple antibioticresistant gram-negative bacterial pathogens. The Society for Applied Microbiology, Journal of Applied Microbiology, 105, 822-828.

Wang, B., Li, B., Liang, Y., Li, J., Gao, L., Chen, L., Duan, K. and Shen, L. (2016). Pleiotropic effects of temperature-regulated 2-OH-lauroytransferase (PA0011) on Pseudomonas aeruginosa antibiotic resistance, virulence and type III secretion system, Microbial Pathogenesis, 91, 5-17. 